\title{
The Global Book Publishing Market as an Interdisciplinary Research Field
}

\author{
Kamila Augustyn \\ ORCID 0000-0002-8395-8470 \\ Institute of Library and Information Science \\ University of Wroctaw, Poland
}

\begin{abstract}
Purpose/Thesis: The article characterizes the research on the global book publishing market to determine the extent of its interdisciplinarity.

Approach/Methods: This article uses quantitative and qualitative analysis of selected academic papers, discipline profiles of their authors and of the journals to investigate which subject area dominate in scientific output of researchers and to establish the relationship between publishing studies and other disciplines on the field of the global book market. In order to prove the relatedness of journals bibliometric methods (co-citation, bibliographic coupling analysis of sources) and knowledge visualization technologies will be used.

Results and conclusions: The selected papers focused on book history and book culture, economics and technological aspects of book publishing, and users' attitudes and preferences. The authors published in journals associated with disciplines such as media \& communication studies and education (Publishing Research Quarterly, Journal of Scholarly Publishing, Learned Publishing), book studies (Logos) and information studies (Electronic Library, Journal of Documentation). In Corpus 1 (C1) there were co-cited trade magazines and academic journals on library and information science, in Corpus 2 (C2) - academic journals mostly focused on marketing and economics. Co-authored publications constituted $42 \%$ of $\mathrm{C} 1$ and $63 \%$ of $\mathrm{C} 2$. The study showed that the research of the global book publishing market is led by interdisciplinary researchers, but rarely by international teams.

Research limitations: The initial corpus of academic papers was narrowed down to 230 articles published in English between 2001 and 2018. The study did not include articles focusing on book markets in the countries that make only slight contributions to the global book publishing industry. The discipline classification adopted in the study follow that of the Scopus database.

Originality/Value: This study provides insight into the research on the global publishing market and proves that it is interdisciplinary.
\end{abstract}

\section{Keywords}

Bibliometrics. Book market. Book publishing. Global book publishing market. Information sources. Interdisciplinarity. Publishing industry. Publishing studies. Scientific journals.

Received: 30 May 2020. Reviewed: 20 June 2020. Revised: 16 July 2020. Accepted: 10 September 2020.

\section{Introduction}

This article emerged from a research study titled "Sources of Information Regarding the Global Book Publishing Market After 2001. Typology and Characterization" driven by an interest in the mechanisms of changes on global book market resulting from the 
technological development, widened access to information and increased prominence multi-channel distribution. The analysis will allow a more detailed characterization of the global book publishing market, with a focus on the sources of information on the subject. The variety, form, type, accessibility, relevance, provenance, reliability, and language of these sources reflects the qualities of the contemporary book publishing market and the dynamics of the transformations occurring in it; they testify to the methods adopted in research and to the communication in trade or in the academic community; they show the shared attitudes and business models; finally, it gestures towards various obstacles to the information flow (systematic, technological, logistical). As a part of the study, a database, "Sources of Information Regarding the Global Book Publishing Market, 2001-2017," was created: it will be developed over the course of further research ${ }^{1}$.

For the purposes of this study, the "global book publishing market" is defined with a reference to production - books and journals - and geography - largest book markets worldwide: the USA, China, Germany, Great Britain, France, Japan, and Spain ${ }^{2}$ (Wischenbart, 2016; 2018) in terms of market value (at consumer prices) and the revenues of the largest publishing companies from the sales of books (physical and digital, hardcover and paperback editions), digital material, academic and trade journals, professional information, and business-to-business book distribution. This definition does not account for the sales of newspapers and magazines, wire services, and media such as radio, television, music, and games (Milliot, 2018; Wischenbart \& Fleischhacker, 2019).

To examine the interdisciplinarity of the studies on the global book publishing market, a corpus of academic papers was distinguished (C1): it comprises academic articles and reviews on the book market in a global perspective, or in the leading countries, published in English between 2001 and 2018.

2001 was a symbolic year, as it marked the new century; it was also the year when the disruptive technologies, and electronic books in particular, became an object of research (Lian, 2010; Lichtenberg, 2011; Overdorf \& Barragree, 2001) 3 $^{3}$ The turn towards e-books was inspired, in a large part, by Stephen King who, together with the Simon\&Shuster publishing house, published Riding the Bullet, the first mass-market e-book in the form of a digital file, in 2000 (Stevenson, 2008, 282-283). In 2002, the trade publishing houses - Harper Collins and Random House - added e-books to their products. 2018 was a natural end-point for the study, as it relies on the analysis of indexed publishing activity.

The assessment and selection of documents required familiarity with hundreds of titles, abstracts, keywords and texts to reject those that were irrelevant, i.e. concerned with book publishing market in the countries, whose contribution to the global publishing industry was only slight. However, these articles were not always disqualified solely on the basis of

1 A special bibliography was created as a part of fulfilling a restructuring grant to increase the efficiency of scientific activity at the Faculty of Letters at the University of Wrocław. A ruling of MNiSW [Ministry of Science and Higher Education] no 6674/E-344/R/2017 from 01.03.2017. Project co-ordinator: dr hab. Bożena Koredczuk, prof. UWr.

2 Spain was included primarily because of large publishing conglomerates such as Grupo Planeta (Milliot, 2018).

3 “«Disruptive technologies» are new technologies that make products cheaper, simpler, smaller, and more convenient to use (...) often have a lower profit margin than sustaining technologies, and therefore require a new concept of product value" (Lian, 2010, 39). 
their focus on the local contexts. If the research they presented allowed a better understanding of larger mechanisms, or if the authors explained emergent patterns, compared and analyzed data from a number of markets, or at least referred to them, to give their study a larger perspective, the articles reached beyond the local cultural context and, as such, they were considered to be relevant to the present study.

The analyzed texts were concerned with three publishing sectors: 1) trade/consumer publishing, 2) educational and 3) professional / academic / scientific-technical-medical / humanities and social sciences (STM \& HSS). Unlike the "[e]xtant research into contemporary book publishing, [which] tends to cohere around five nodal points: industry research and vocational information; personalised accounts such as memoirs, autobiographies, biographies and house histories; the history of the book; communication, media, cultural studies and sociology; and nationalist and post-colonial studies," discussed by Simone Murray $(2006,4)$, this paper focuses on the content of the articles and distinguishes four research areas in the field of global publishing market studies. The discussion of the various aspects of book publishing employs terms similar to those proposed by Rojers P. Joseph in his research of higher education book publishing (2015): technological elements of book publishing (digital and electronic publishing, disruptive technologies, information technology, digitization, formats, platforms, apps, devices, digital developments, content management), user attitudes and preferences (reading habits, usage patterns, user experience, design), economics of book \& journals publishing (price, revenues, sales and purchase patterns, business models, international investments, mergers \& acquisitions, fairs, market reports, marketing of books, supply chain, distribution, copyright issues and permission barriers, open access), book history \& book culture (history of publishing, authors, editors, publishers, booksellers, genres, types of books, journals, storytelling, translation, diversity). The analyzed articles were categorized accordingly on the basis of their dominant themes. The multiplicity of authors' research approaches was apparent in their employment of methods from various disciplines, and, occasionally, from various fields.

This paper proves that the research on the global book publishing market is interdisciplinary. The qualitative analysis of the articles allowed to establish the discipline affiliation of the research questions discussed by the authors. In the next stage, the discipline profiles of the authors and the academic journals in which they published were outlined. The organization of the publication structure was analyzed with the use of bibliometrics (co-citation analysis, bibliographical coupling analysis of sources) and knowledge visualization technologies to identify the core journals, and to establish the relations between them.

The study did not include monographs, academic textbooks, and conference publications. They merit a discussion of their own, and a detailed analysis. Course syllabi reading lists may be studied as well, as Pehar \& Selthofer suggest (2015).

The initial corpus (C1) comprised 230 academic articles authored by 247 researches. Despite the apparent prominence of two journals - Logos and Publishing Research Quarterly (PRQ), the corpus was intended to represent the variety of publications, research questions, disciplines, and methodologies. Bibliographic data and discipline classification derive from Scopus, which might be a limitation, as Zbigniew Osiński argued (2019, 49); therefore, the discipline classification was also an object of a qualitative study - an analysis of the titles, abstracts and methods of the select articles. The data were collected between 2017 and 2020, and revised in April of 2020. 


\section{Research areas in global book publishing studies}

\subsection{Book history and book culture}

The corpus was dominated by the articles concerned with the economic aspect of the publishing process and the history and culture of the book. However, the modifications of the value chain and distribution, resulting from the development of information technologies, make the users' needs and preferences increasingly important; therefore, more scholars turn toward technology and use.

The category of 'book history and book culture' encompassed publications from the disciplines of literary studies, book studies, cultural studies and sociology. It included articles on the culture of reading (Kovač, 2007), bibliographies of market products or sectors, e.g. scholarly publishing (Bailey, 2001; Greco, 2005), analyses specific types of books: textbooks (Friesen, 2013), academic monographs (Williams et al., 2009), comic books (Brienza, 2009; 2010), books for children and young adults (Marcus, 2016), bestsellers as a form offering "insights into the cultural logic of book markets" (Kovač \& Wischenbart 2010; 2018). They also included articles concerned with history, structure, and issues of academic or trade publishing houses and university presses ${ }^{4}$ (Clare, 2014; Kernan, 2013; Mannana-Rodriguez \& Giménez-Toledo, 2018), with the role of publishers with symbolic capital in the access of writers to global market (Sapiro, 2017), as well as texts devoted to bookshops as curators of books (Steiner, 2017) and new methods of book-store management in the digital era (Emblidge 2012; 2013; 2016).

The largest part of the analyzed texts was concerned with bibliodiversity (Benhamou \& Peltier, 2007; Hawthorne, 2016), discussed mostly in the community of French economists and sociologists (Peltier, Benhamou, Sapiro). Bibliodiversity is fostered by small and independent publishers (Bold, 2015; 2016), release and promotion of diverse books (Shea et al., 2018), concerned with cultural, racial, and gender differences (Bold, 2018; Moeller \& Becnel, 2018), books translated from less widely-spoken languages (Ban, 2015; Bold \& Norrick-Rühl, 2017; Sapiro, 2010), authored by writers from communities marginalized by the West (Bold, 2018). Scholars concerned with bibliodiversity also seek to analyze the barriers present on the labor market in the publishing industry (Fröhlich 2014) and try to define changing relations in the publishing hierarchy (Carolan \& Evain, 2013). Such discussions of the importance of diversity and of the resistance to the dominant discourses are founded on Pierre Bourdieu's concepts of cultural capital and symbolic violence (Haeusermann, 2013; Sapiro, 2008; 2015; Thomlison \& Bélanger, 2015). Sapiro analyzed the role of literary awards and festivals in the context of material and ideological conditions of production (Sapiro, 2016). Others studied the ways in which the communities of writers and fans/readers are created (Patterson \& Brown, 2009; Squires, 2004), the digital ecosystem of the literary sphere (Murray, 2016), and literary celebrities (Ohlsson et al., 2014).

Many articles in the category of book history and book culture belong to more than one category. Such was the case of papers on posing the question of whether globalization and digitalization further the commercialization of culture and make the publishing

\footnotetext{
${ }^{4}$ We distinguish university presses, trade presses, and commercial academic presses (Striphas, 2002, 443).
} 
industry more market-oriented (Martin et al., 2018; Von Rimscha \& Putzig, 2013), and whether they change the circulation of books in specific countries, or language spheres (Steiner, 2018).

\subsection{Economics of publishing}

The articles focused on the mechanics of publishing industry frame the book as a product, rather than a cultural artifact, subject to theoretical or aesthetic reflection. Authors prioritized marketing issues: brand phenomenona such as Harry Potter (Brown \& Patterson, 2010), purchase habits of individual and institutional consumers (e.g., academic libraries), the methods of sales measurement (Andrews \& Napoli, 2006; Gallagher \& Bohme, 2009), market, and the influence of various factors on sales: the form and formats of the book (Asai, 2015; 2016; Li et al., 2015; Schmidt-Stölting et al., 2011), its type (literary and popular fiction), genre, price, and distribution model (wholesale model or agency model), the time it entered the circulation, sales channels, presence on the bestseller lists (Feather \& Woodbridge, 2007; Sorensen, 2007), publicity (Zhang, 2008), the type of contract signed by the author (royalty or buy out arrangements) (Hao \& Fan, 2014), library loans (Burleigh, 2017). The researchers also tested the reality of the long-tail effect phenomenon, referring to the indicators of presence in media (Peltier et al., 2016). They predicted the consequences of mergers and acquisitions (Peltier, 2004), digitization (Buschow et al., 2014), or the results of the concentration of media properties, including its influence on the distribution of "quality literature" (Rimm, 2014). Others analyzed the variances in interest in a book depending on its form (Costa-Knufinke, 2012; Vasileiou et al., 2009) and the reasons behind the global expansion of e-books (Herther, 2005; Weinstein, 2010); they considered various business models and innovative ways of value creation in the realm of mass production and distribution, and of communication between the publisher and the consumers (Faherty, 2013). Scholars also raised the issue of marketing budget allocation. According to Shehu and others, publishing houses should devote a larger part of their budget to promote promising books by lesser known authors (Shehu et al., 2014).

Many papers were concerned with the development and structure of a given market, its size, publishing industry, the largest publishing houses, their revenue, price strategies, internationalization and the challenges posed by digitization (Birtle, 2011; Himma \& Just, 2007; House, 2013; Liu, 2008; Magadán \& Rivas, 2018; Xiaomei, 2011; Xu \& Fang, 2008). Papers discussing the planning and management of university presses, their price politics and digital sales models (Greco, 2001; Greco et al., 2012; Greco \& Spendley, 2016) were also categorized as focused on the economics.

The scholars agreed that the absence of data regarding a number of aspects of the book circulation, and the incomparability of available data, resulting from the disparity between the definitions assumed over the course of data collection seriously limited their research (Kovač et al., 2017). The issues of property rights in the case of mass-produced multi-format cultural goods distributed across many channels are another challenge to the publishing industry (Beetz, 2008; Striphas, 2006; 2009; Williams, 2011). 


\subsection{Technology and usability}

Researchers analyzed the influence of information and communication technologies (ICT) on the information systems and education (Roosendaal et al., 2003), and proposed innovative solutions to promote products of university presses as to increase their visibility and sales (Esposito, 2010; Greco \& Aiss, 2015). They suggested a consolidated catalogue for university presses and a non-profit website for the consumers, consistently generating data on sales and marketing. It would harness big data and predictive analysis to the needs of higher education. The scholars signaled the necessity of transforming the distribution, selection and preparation of available content for education, which should be better suited to the consumers' needs and involve them in effective (e)learning, based on practices beyond reading specific materials (Tian \& Martin, 2013). David Emblidge suggested "a publishing studies online academic database available by subscription from a major academic publisher, reflecting publishing practices worldwide", containing "variety of teaching and learning tools" $(2015,178)$. Papers on e-books analyzed definitions, preservations activities and methods of (re)presentation of content on platforms of various types (Machovec, 2018; Tovstiadi \& Wiersma, 2016), facilitating library purchases (Forzetting et al., 2012; Vasileiou et al., 2012), as well as the readers' attitudes and behaviors, the influence of screen-based technologies (Mangen \& van der Weel, 2016) and cultural differences, of education systems specific to each country, and of the level of socio-economic development, on the preferences regarding the format of the book and reading habits (Kovač \& van der Weel, 2018; Shimray et al., 2015). The research subjects were usually students at a university, or a number of universities (Mizrachi et al., 2018). The scholars also studied the publishers' attitudes and their capacity for adjustment, as well as new start-ups (McIlroy, 2017).

\section{Methodology review}

Two contrasting approach emerge from the analysis of studies of the global book publishing market published between 2001 and 2018: the academic approach, which seeks to delve into the nature of the studied object and to situate it in a historical and socio-cultural context, and the pragmatic and summary approach of the publishing trade representatives. Often, the former is termed "publishing studies", and the latter - "book/publishing business". The former is dominated by qualitative multi-aspect studies small samples borrowing the methods of social sciences: sociology, social communication and media studies, as well as history, culture studies, and literary studies. In the latter, quantitative studies of relations between phenomena or variables conducted with mathematical and statistical methods by economists are more prominent.

The data on the readers' preferences and habits, the creation of library collections, the state and structure of the trade, the attitudes and activities of the publishing houses' employees, the publishers' strategies, readiness to change their business models, solutions to the problems of digitization, and the role the small publishers play in the local communities, are usually collected by surveys and interviews. The research also relies on the testimonies from the representatives of the publishing trade. 
Market subjects and products are studied using methods of case study, content analysis, close reading, ethnographic observation, and netnography. Many papers offer a review of scholarship, combined with the analysis of data and trends (network, time-trend analysis), studies of specific cases and comparative analysis. The comparison of the results from a specific research with data from other markets allows the author to make predictions regarding the further development of a given sector, product, or trend. The basic source of data for such studies are trade reports of book market analysts, associations (e.g. Association of American Publishers, Book Industry Study Group), databases, surveys conducted by various institutions (Bowker - Pub Track Consumer; BML, a British agency - Books \& Consumers) and data providers, such as the Nielsen BookScan firm. P.E.S.T. (Political, Economic, Socio-Cultural, and Technological factors) and S.W.O.T. (Strengths, Weaknesses, Opportunities, and Threats aspects) analyses are conducted basing on data from these sources, and from the national readership surveys, as well as on demographic data and data regarding purchasing habits. They yield the fullest characterization of the book market in a given country and of the competitive environment of publishing companies, facilitating management. Studies on the influence of factors such as the degree of acceptability and utility for the customer, the cost of technology, cannibalization of distribution channels, the strength and reach of a brand, the asymmetry of information, are also important. To this end, economists project market scenarios, based on, e.g., the game theory (Alptekin, 2015; Hin \& Li, 2012); they conduct the analysis of statistic correlation, and employ mathematic modelling (Artiles et al., 2013; Hao \& Fan 2014; Hu \& Zhang 2016).

\section{The position of the discipline}

Many attempts have been made to situate publishing studies in relation to other disciplines. The first decade of this century brought a renewed interest in the issue. The specifics of academic study are a subject of discussion, as are teaching programs. Jonathan Rose lists the examples of publishing programs in various countries. Publishing and Printing Arts at Pacific Lutheran University (Tacoma, Washington) offers courses that reflect the contents, and the interdisciplinary nature of this research field: The Book in Society borrows from history of literature, book studies and sociology; The Art of the Book involves designing a book and its reception; Publishing Procedures is oriented towards professional development (Rose, 2003, 16) ${ }^{5}$. The role publishing education play in professional and academic development is also discussed by Miha Kovač (2007), Masha Stepanova (2007), Alison Baverstock and Jackie Steinitz (2014). Kovač emphasizes also important role of developing research programs and reviews the most important sources of information on the subject: books and journals such as Publishing Research Quarterly, Logos, International Journal of the Book.

Simone Murray verifies the discipline's methodology and notes "the lack of engagement with cultural politics", criticizes academic researchers preference for description over critical analysis and "adopt the mode of industry [not research - K.A.] surveys" (Murray, 2006, 5, 7).

\footnotetext{
${ }^{5}$ https://www.plu.edu/ppa/publishing-resources/
} 
According to her, this preference is a result of the excessive reliance on the sources such as reports, industry updates, vocational guides and memoirs, biographies, house histories, essays authored by members of the publishing trade. The insights they offer age quickly, or fail to reach beyond their subjective experience; although they provide the researchers with valuable, otherwise unavailable information, they can never suffice by themselves, or be verified. Therefore, they are often used to comment on the state of knowledge, rather than to expand it.

The thematic analysis conducted in this paper showed that the business approach (the book as a commodity) competes with the cultural ("book as itself an agent in complex global cultural flows," Murray, 2006, 6). However, they share the idea that book is an object distributed by different channels, that changes its form and structure under the influence of socio-cultural, economical, and technological transformations.

Book (history) studies, in which the book is defined "broadly to take in periodicals, manuscripts, letters, ephemera, and even websites as well as books per se" (Rose, 2003, 11-12), analyzes the dynamic of the book market's development (transformations of book production), and of the books themselves as products of their time, the tools of communication and culture with the methods and paradigms borrowed from bibliography, book and literary studies, sociology and economic history, among others (Murray, 2006, 9; Stepanova, 2007).

Media studies extend the concept of the market to account for products so it becomes a media-publishing market, a part of the creative sector. It threatens to blur the research field, as the book has to compete with other media formats. However, it allows an understanding of the book as a phenomenon emergent in the interaction with other formats, and to see the mutual conditioning of media products and their marketing, as well as the transformation of book's form and reception.

Equally important is the study of the influence of the information technology on the management of communication and information flow (the access to information on the book publishing market), and the following distribution of information contained in books and journals. Thus framed, book industry preserves areas of knowledge. Donald Hawkins showed most clearly how the issues of book industry fit into the schemes of information science. He distinguished two sub-fields of information sciences that correspond to the book industry: The Information Industry (Information \& knowledge management; Markets \& players; Economics \& pricing; Marketing, e-commerce), and Publishing \& Distribution (Print; Electronic: e-journals, e-books; Secondary publishing; Scholarly communication) (Zins, 2007, 657). In the schemes of other researchers, the book market issues figures as Economics of Information: Information Industry, Information and Media Products (Capurro); The Information Market: Publishers, Consumers, Publication media, Marketing \& Advertising Information Professionals \& Services (Moukdad); Systems \& Products and Societal Dimensions (Menou). 


\section{Disciplinary classification of scholars and journals}

\subsection{Corpus 1 - scholars}

To see if the authors of the select articles employ an interdisciplinary approach in their research, their discipline profiles in the Scopus database were analyzed ${ }^{6}$. The sample was restricted to 65 scholars, who authored at least two articles from $\mathrm{C} 1$. Together, they wrote 151 out of $230(66 \%)$ articles in C1. Table 1 presents the total number a given discipline featured in the profiles of the authors.

Tab. 1. Total number of subject areas and fields of 65 authors from $\mathrm{C} 1$

\begin{tabular}{|c|c|c|c|c|c|c|c|}
\hline \multicolumn{2}{|c|}{ Social Sciences } & \multicolumn{2}{c|}{ Physical Science } & \multicolumn{2}{c|}{ Health Science } & \multicolumn{2}{c|}{ Life Sciences } \\
\hline SS & 64 & CS & 56 & Med. & 11 & BGMB & 4 \\
\hline BMA & 51 & E & 47 & HP & 3 & ABS & 3 \\
\hline AH & 43 & M & 17 & N & 1 & IM & 2 \\
\hline EEF & 18 & ES & 6 & & & Neu & 1 \\
\hline DS. & 12 & EPS & 5 & & & PTP & 2 \\
\hline P & 8 & Energy & 3 & & & & \\
\hline & & MS & 2 & & & & \\
\hline & & CHE & 1 & & & & \\
\hline & & PA & 1 & & & & \\
\hline
\end{tabular}

$71 \%$ of the scholars were associated with five or more disciplines. The number ranged between two and 12. Two main subject areas featured in almost all profiles: Social Sciences (SS, BMA, and AH) and Physical Science (CS and E). The profiles of eight out of 11 researchers with the highest Hirsch index (above 10) featured eight or more disciplines.

The effect of collaboration between scholars was tested as well. Ninety-seven (42\%) out of 230 select articles were a result of such a collaboration. Six research teams, whose at least three papers featured in C1, are compared in Table 2. Together, their members published 25 articles ( $11 \%$ of $C 1$ ). The members of five out of six research teams worked at the same institution. The profiles of 10 scholars out of those 13 involved in the research teams featured at least five disciplines (SS, CS, BMA, E, and AH). The number of the

${ }^{6}$ The names of the subject areas and fields were abbreviated as follows: ABS: Agricultural and Biological Sciences; AH: Arts and Humanities; AH: LL - Language and Linguistics; AH: LLT - Literature and Literary Theory; AH: VA - Visual Arts and Performing Arts; BGMB: Biochemistry, Genetics and Molecular Biology; BMA: Business, Management and Accounting; $\mathrm{CH}$ : Chemistry; CHE: Chemical Engineering; CS: Computer Science; D: Dentistry; DS: Decision Sciences; E: Engineering; EEF: Economics, Econometrics and Finance; E: MT - Engineering: Media Technology; EPS: Earth and Planetary Sciences; ES: Environmental Science; HP: Health Professions; IM: Immunology and Microbiology; M: Mathematics; Med: Medicine; MS: Material Science; N: Nursing; Neu: Neuroscience; P: Psychology; PA: Physics and Astronomy; PTP: Pharmacology, Toxicology and Pharmaceutics; SS: Social Sciences; SS: E - Social Sciences: Education; SS: C - Communication; SS: CS - Social Sciences: Cultural Studies; SS: Law; SS: LIS - Library and Information Science; SS: LL - Linguistics and Language. 
disciplines featured varied, especially in the first team. In each team, one member had a markedly higher number of citations, but their h-index were relatively similar. As the data from Scopus shows, the lesser cited authors' most cited papers were precisely these co-authored with the researchers that were more widely-cited, with a broader, or slightly different discipline profile.

Out of the 91 multi-author articles ${ }^{7}$ as many as 73 (80\%) were a result of a collaboration between the researchers from the same country, while $53(58 \%)$ originated at the same institution. Eighteen (20\%) articles were a result of an international collaboration (e.g. Kovač/Wischenbart; Kovač/van der Weel; Bold/Norrick-Rühl). This data suggests that the research on the global book publishing market is rarely international, even if it is interdisciplinary.

Tab. 2 Research teams based on the number of co-authored articles in C1 (min. 3)

\begin{tabular}{|c|c|c|c|c|c|}
\hline Team & Authors & $h$-index & $\begin{array}{c}\text { Total } \\
\text { citations }\end{array}$ & $\begin{array}{l}\text { Number of } \\
\text { disciplines }\end{array}$ & Affiliation \\
\hline \multirow{3}{*}{1} & Jennifer Rowley & 49 & 8367 & 11 & \multirow{3}{*}{$\begin{array}{c}\text { Manchester Metropolitan } \\
\text { University Manchester, } \\
\text { United Kingdom }\end{array}$} \\
\hline & Richard Hartley & 7 & 228 & 6 & \\
\hline & $\begin{array}{l}\text { Magdalini } \\
\text { Vasileiou }\end{array}$ & 5 & 146 & 2 & \\
\hline \multirow[b]{2}{*}{2} & Albert N. Greco & 8 & 175 & 6 & \multirow{2}{*}{$\begin{array}{l}\text { Fordham Univeristy, } \\
\text { United States }\end{array}$} \\
\hline & $\begin{array}{l}\text { Robert M. } \\
\text { Wharton }\end{array}$ & 5 & 69 & 5 & \\
\hline \multirow{2}{*}{3} & Bill Martin & 10 & 278 & 6 & \multirow{2}{*}{$\begin{array}{l}\text { Swinburne University } \\
\text { of Technology, Australia }\end{array}$} \\
\hline & Xuemei Tian & 7 & 131 & 9 & \\
\hline \multirow{2}{*}{4} & Qing Fang & 5 & 62 & 8 & \multirow{2}{*}{$\begin{array}{l}\text { Wuhan University, } \\
\text { Wuhan, China }\end{array}$} \\
\hline & Lifang Xu & 4 & 38 & 5 & \\
\hline \multirow[b]{2}{*}{5} & Miha Kovač & 4 & 70 & 5 & $\begin{array}{c}\text { University of Ljubljana, } \\
\text { Slovenia }\end{array}$ \\
\hline & $\begin{array}{c}\text { Rüdiger } \\
\text { Wischenbart }\end{array}$ & 4 & 32 & 5 & $\begin{array}{c}\text { Content and Consulting, } \\
\text { Vienna, Austria; } \\
\text { Inštitut za Germanistiko } \\
\text { Univerze na Dunaju, Austria }\end{array}$ \\
\hline \multirow[b]{2}{*}{6} & $\begin{array}{l}\text { Gabrielle } \\
\text { Wiersma }\end{array}$ & 3 & 33 & 3 & $\begin{array}{l}\text { University of Colorado Boulder, } \\
\text { United States }\end{array}$ \\
\hline & Esta Tovstiadi & 2 & 11 & 2 & $\begin{array}{l}\text { University of Colorado Boulder, } \\
\text { United States; The State Uni- } \\
\text { versity of New York at Potsdam, } \\
\text { Potsdam, NY, United States }\end{array}$ \\
\hline
\end{tabular}

7 The institutional affiliations of authors of the six articles were not identified. 


\subsection{C1 - journals}

Half of the articles included in C1 was published in one of two academic journals: 41\% (94) were published in Publishing Research Quarterly (PRQ), 10\% (22) in Logos - Journal of the World Publishing Community, 13 in Journal of Scholarly Publishing, eight in Electronic Library, six in Learned Publishing, five in Journal of Cultural Economics, four in International Journal of the Book ${ }^{8}$, three in Journal of Media Economics, Journal of Electronic Publishing and Online Information Review (in total 70\% of the articles was published in these 10 journals).

The classification of these journals was as follows:

- Social Sciences \& Humanities ${ }^{9}$, mainly: SS: LIS - 25 (27), SS: C - 7 (8), SS: CS - 4 (6), SS: E - 3 (6); Arts \& Humanities - 12 (13), mainly AH: LLT - 7; BMA - 6 (13); $\mathrm{EEF}-3(5)^{10}$;

- Physical Sciences, mainly E: MT - 3 (4) and CS - 1 (15).

Table 3 presents the journals which published at least two articles from $\mathrm{C} 1$, and identifies the disciplines on whose rankings these journals had the highest positions. Of the 18 titles, AH represents $4(5)^{11}, \mathrm{SS}: \mathrm{C}-4$ (5), SS: LIS - 4, CS - 2 (6), and E: MT - 2 (3). The highest number of the articles from the entire corpus was published in the journals with positions on the rankings of AH - 38 (40), SS: LIS - 36 (38), SS: C - 16 (110), and CS - 3 (28).

The number of articles published in the journals ranked on the list of SS: C bolstered by $P R Q$, whose second highest position on the ranking of SS: $\mathrm{C}$ - it published most of the relevant articles. However, it ranks higher on the list of E: MT, because of its focus on new technologies, media, and digital culture. $P R Q$ "examines the social, political, economic, and technological conditions that shape the publishing process; provides a platform to present new developments in digital multimedia publishing; explores product development, marketing, financial aspects, and print and online distribution" as we may read on the journal's website ${ }^{12}$.

Logos "features articles from and about the publishing world, illustrating the unity, commonality, and conflicting interests of those who write, edit, manufacture, publish, disseminate, preserve, study, and read published works. Logos is international and intercultural, bridging gaps between academia and business, the developing and developed worlds, printed and digital media" ${ }^{13}$. The second highest position of Logos is on the E: MT list, but it ranks higher on the list of AH: LLT. Out of the studied journals, Journal of Scholarly Publishing (JSP) ranks highest on the E: MT list. JSP "is the indispensable resource

${ }^{8}$ Current Title: Information, Medium, and Society: Journal of Publishing Studies (since 2020) ISSN: 2691-1507, e-ISSN: 2691-1515, https://informationmediumsociety.com/journal

9 Several journals were associated with more than one field of study. The classification follows that of the Scopus database, accounting for the journal's highest and second highest position in the disciplines' ranking (Category 1 and Category 2, respectively). The total number of journals whose highest or second highest position is on ranking of a given discipline follows in the parentheses. See: https://service.elsevier. com/app/answers/detail/a_id/14882/supporthub/scopus/ /what-are-the-most-frequent-subject-areacategories-and-classifications-used-in/

10 See: footnote 6.

11 Five if the journal whose second-highest position was on the $\mathrm{AH}$ list is included.

12 Publishing Research Quarterly, Springer, https://www.springer.com/journal/12109

13 Logos, Brill, https://brill.com/view/journals/logo/logo-overview.xml 
for academics and publishers that addresses the new challenges resulting from changes in technology, funding and innovations in publishing (...) JSP has also examined the future of scholarly publishing, scholarship on the Web, digitization, copyright, editorial policies, computer applications, marketing, and pricing models" ${ }^{14}$.

Bibliometrics showed that the marketing journals are largely dispersed and make only a slight contribution.

Tab. 3 Subject areas and fields of journals from C1 (min. 2 documents)

\begin{tabular}{|c|c|c|c|c|c|c|c|}
\hline No. & Title & $\begin{array}{l}\text { Docu- } \\
\text { ments }\end{array}$ & ISSN & $\begin{array}{l}\text { Catego- } \\
\text { ry } 1\end{array}$ & $\begin{array}{l}\text { Per- } \\
\text { centile }\end{array}$ & $\begin{array}{l}\text { Catego- } \\
\text { ry } 2\end{array}$ & $\begin{array}{c}\text { Per- } \\
\text { centile }\end{array}$ \\
\hline 1 & $\begin{array}{l}\text { Publishing Research } \\
\text { Quarterly }\end{array}$ & 94 & $1053-8801$ & E: MT & 64th & SS: C & 47th \\
\hline 2 & Logos (Netherlands) & 22 & $0957-9656$ & AH: LLT & 74th & E: MT & 40th \\
\hline 3 & $\begin{array}{l}\text { Journal of Scholarly } \\
\text { Publishing }\end{array}$ & 13 & $1198-9742$ & E: MT & 73rd & SS: E & 57 th \\
\hline 4 & Electronic Library & 8 & 0264-0473 & SS: LIS & 80th & CS & 48th \\
\hline 5 & Learned Publishing & 6 & 0953-1513 & SS: C & 83rd & & \\
\hline 6 & $\begin{array}{l}\text { Journal of Cultural } \\
\text { Economics }\end{array}$ & 5 & 0885-2545 & EEF & 88th & & \\
\hline 7 & $\begin{array}{l}\text { International Journal } \\
\text { of the Book }\end{array}$ & 4 & $1447-9516$ & AH: LLT & 7th & AH: $\mathrm{H}$ & 4th \\
\hline 8 & $\begin{array}{l}\text { Journal of Electronic } \\
\text { Publishing }\end{array}$ & 3 & $1080-2711$ & CS & 6th & & \\
\hline 9 & $\begin{array}{l}\text { Journal of Media } \\
\text { Economics }\end{array}$ & 3 & $0899-7764$ & SS: C & 50 th & EEF & 36th \\
\hline 10 & Online Information Review & 3 & $1468-4527$ & SS: LIS & 89th & CS & 75th \\
\hline 11 & Convergence & 2 & $1354-8565$ & SS: C & 74th & $\mathrm{AH}$ & 64th \\
\hline 12 & First Monday & 2 & $1396-0466$ & SS: Law & 87th & $\mathrm{CS}$ & 55th \\
\hline 13 & Javnost & 2 & $1318-3222$ & SS: C & 63rd & & \\
\hline 14 & Library Hi Tech & 2 & $0737-8831$ & SS: LIS & 82nd & $\mathrm{CS}$ & 48th \\
\hline 15 & PLOS ONE & 2 & $1932-6203$ & Multi & 90th & $\begin{array}{c}\text { Agri- } \\
\text { cultural }\end{array}$ & 89th \\
\hline 16 & Poetics & 2 & $0304-422 X$ & $\begin{array}{c}\text { SS } \\
\text { CS } \\
\text { AH: LLT }\end{array}$ & 99th & $\begin{array}{l}\text { AH: LL } \\
\text { SS: LL }\end{array}$ & 96th \\
\hline 17 & Primerjalna Knjizevnost & 2 & 0351-1189 & AH: LLT & $41 \mathrm{st}$ & & \\
\hline 18 & Serials Librarian & 2 & 0361-526X & SS: LIS & 45th & & \\
\hline
\end{tabular}

${ }^{14}$ Journal of Scholarly Publishing, University of Toronto Press, https://utorontopress.com/us/journal-of scholarly-publishing 
Articles from C1 were published in 71 journals, with a half published in PRQ and Logos. An analysis with the use of VOSviewer software version 1.6.14 (Van Eck \& Waltman, 2010) showed that these journals had the highest combined number of bibliographical couplings (total link strength - TLS), with other journals from the list and between each other (126 TLS). Their citations related them to International Journal of the Book (43 TLS with PRQ), Primerjalna Knijezevnost and Convergence (Tab. 4). Journal of Scholarly Publishing (28 TLS with PRQ), Journal of Electronic Publishing, Learned Publishing, First Monday and PLOS One formed another, larger cluster. However, these journals were largely dispersed, and the link between them was not very strong - most likely due to the relatively small number of articles in $\mathrm{C} 1$.

The larger number of citations (315) was registered for the PRQ, but it did not reflect popularity of the journal. The number of citations of a source equals the total number of citations that the documents of the source (only this from C1) have received in Scopus. High citation number of a specific article was the case with the journals PLOS One (Laakso et al., 2011), Library Hi Tech (Vassiliou, 2008), and Poetics (Sapiro, 2010).

Tab. 4 Bibliographic coupling of journals from $\mathrm{C} 1$

(min. 2 documents, 2 citations, TLS $>0$ )

\begin{tabular}{|c|l|c|c|c|}
\hline No. & \multicolumn{1}{|c|}{ Title } & Documents & TLS & Citations \\
\hline 1 & Publishing Research Quarterly & 94 & 323 & 315 \\
\hline 2 & Logos (Netherlands) & 22 & 207 & 20 \\
\hline 3 & Journal of Scholarly Publishing & 13 & 52 & 66 \\
\hline 4 & Electronic Library & 8 & 26 & 134 \\
\hline 5 & Learned Publishing & 6 & 22 & 26 \\
\hline 6 & Journal of Cultural Economics & 5 & 43 & 72 \\
\hline 7 & International Journal of The Book & 4 & 56 & 7 \\
\hline 8 & Journal of Media Economics & 3 & 41 & 75 \\
\hline 9 & Online Information Review & 3 & 18 & 86 \\
\hline 10 & Journal of Electronic Publishing & 3 & 5 & 15 \\
\hline 11 & First Monday & 2 & 40 & 17 \\
\hline 12 & Primerjalna Knjizevnost & 2 & 39 & 5 \\
\hline 13 & Poetics & 2 & 34 & 95 \\
\hline 14 & Convergence & 2 & 28 & 7 \\
\hline 15 & Javnost & 2 & 17 & 12 \\
\hline 16 & Library Hi Tech & 2 & 15 & 113 \\
\hline 17 & Plos One & & 299 \\
\hline
\end{tabular}

Co-citation analysis of sources may be imprecise when applied to a specific value (which might be lower) because it requires manual standardization of titles. However, it showed high TLS for the sources of trade information, e.g. Publishers Weekly, Information Today, Library Journal, and academic journals, Electronic Library, PRQ, Library Hi Tech (Tab. 5). 
Tab. 5 Top co-cited sources from C1 (min. 5 citation and 2000 TLS)

\begin{tabular}{|c|l|c|c|}
\hline No. & \multicolumn{1}{|c|}{ Title } & TLS & Citations \\
\hline 1 & Publishers Weekly & 23254 & 109 \\
\hline 2 & Information Today & 12010 & 39 \\
\hline 3 & Library Journal & 9779 & 34 \\
\hline 4 & Electronic Library & 3775 & 11 \\
\hline 5 & Publishing Research Quarterly & 3554 & 139 \\
\hline 6 & Library Hi Tech & 3503 & 34 \\
\hline 7 & Online & 2864 & 16 \\
\hline 8 & Logos & 2466 & 45 \\
\hline 9 & Against the Grain & 2402 & 18 \\
\hline 10 & Electronic Engineering Times & 2379 & 9 \\
\hline 11 & Computers in Libraries & 2365 & 10 \\
\hline 12 & Seybold Report on Internet Publishing & 2262 & 6 \\
\hline 13 & Technology Review & 2262 & 6 \\
\hline
\end{tabular}

\subsection{Corpus 2 - scholars}

Corpus 2 (C2) comprised all publications indexed in Scopus by the scholars who authored at least two articles on the global book publishing market featured in C1. C2 was created to identify the most important sources of papers on the book market, on a larger sample and to test the connection between the journals based on the number of times they are cited together (co-citation analysis) and the number of references they share (bibliographic coupling analysis).

C2 comprised 1723 texts published between 1978 and 2020. 1337 were published in journals. 882 met the general criteria (an article, a review, or a short survey in English published between 2001 and 2018). They were published in 301 journals. 130 journals published at least two of these articles. 1014 articles out of 1723 (59\%) were a result of a collaboration; out of the 882 articles meeting the criteria, $552(63 \%)$ were a result of a collaboration which is a larger proportion than in the C1 (42\%). Out of the 539 multi-author articles with affiliation to institution, 170 (31\%) were a fruit of an international collaboration, and $369(68 \%)$ of a collaboration between the researchers from the same country, out of which 211 (39\%) emerged from one institution.

Thirty-seven (57\%) out of the 65 authors whose profiles featured more than four disciplines published their work in more than four journals, out which 14 (22\%) published in a number of journals double the number of the disciplines in their profiles, and five (8\%) published in a number of journals triple the number of the disciplines in their profiles. Approximately 10 to $20 \%$ of the researchers were active in multiple research fields and published in a number of journals with varied discipline profiles. However, an analysis of the publications comprising $\mathrm{C} 1$ showed that the researchers whose discipline profiles were less varied (they featured less than 10 disciplines; usually four to six), and who published 
in a similarly low number of journals, might have been more important (Tab. 6). However, this hypothesis should be tested further.

Tab. 6 Key researchers based on number of articles in C1 (min. 4)

\begin{tabular}{|c|c|c|c|c|c|}
\hline No. & Author & $\begin{array}{c}\text { Number of } \\
\text { articles in } C 1\end{array}$ & $\begin{array}{c}\text { Number of all } \\
\text { documents } \\
\text { (Scopus) }\end{array}$ & $\begin{array}{c}\text { Number } \\
\text { of disciplines } \\
\text { (Scopus) }\end{array}$ & $\begin{array}{c}\text { Number } \\
\text { of journals } \\
\text { (Scopus) }\end{array}$ \\
\hline 1 & A.N. Greco & 13 & 37 & 6 & 6 \\
\hline 2 & D. Emblidge & 6 & 12 & 5 & 3 \\
\hline 3 & M. Kovač & 6 & 22 & 5 & 5 \\
\hline 4 & J. Rowley & 6 & 309 & 11 & 92 \\
\hline 5 & R.M. Wharton & 6 & 13 & 5 & 4 \\
\hline 6 & M.R. Bold & 5 & 13 & 5 & 5 \\
\hline 7 & C. Brienza & 5 & 16 & 5 & 10 \\
\hline 8 & R. Hartley & 5 & 31 & 6 & 11 \\
\hline 9 & S. Peltier & 5 & 8 & 4 & 6 \\
\hline 10 & G. Sapiro & 5 & 57 & 4 & 25 \\
\hline 11 & M. Vasileiou & 5 & 6 & 2 & 5 \\
\hline 12 & G. Wiersma & 5 & 16 & 3 & 7 \\
\hline 13 & L. Xu & 5 & 10 & 5 & 5 \\
\hline 14 & S. Asai & 4 & 22 & 7 & 9 \\
\hline 15 & Q. Fang & 4 & 26 & 8 & 10 \\
\hline 16 & B. Martin & 4 & 36 & 6 & 16 \\
\hline 17 & S. Murray & 4 & 17 & 5 & 11 \\
\hline 18 & H.E. Roosendaal & 4 & 18 & 9 & 13 \\
\hline 19 & X. Tian & 4 & 21 & 9 & 7 \\
\hline 20 & E. Tovstiadi & 4 & 6 & 2 & 5 \\
\hline 21 & A.van der Weel & 4 & 22 & 5 & 9 \\
\hline 22 & R. Wischenbart & 4 & 13 & 5 & 4 \\
\hline
\end{tabular}

\subsection{Corpus 2 - journals}

$P R Q$ published the highest number of the articles from C2 (74), followed by Logos (51). However, they constitute a smaller part of $\mathrm{C} 2$ than they did of $\mathrm{C} 1-$ only $10 \%$. The disparity between the contributions of each journal also lessened. An analysis of the 882 articles comprising $\mathrm{C} 2$ shows that 325 (36\%) was published by 18 journals, 274 (31\%) by 58, and 279 (32\%) by 225 . The ratio is, approximately, 1:3:12 (Tab. 7).

Nine out of these 18 journals were included in $\mathrm{C} 1$; four of these published the highest numbers of the articles on a given subject (in bold type). They were associated with the following disciplines: E: MT, AH: LLT, and SS: C. The titles in grey, absent in C1, extend 
the set of the journals considered, mostly those associated with SS: LIS and BMA. Because of the high number of disciplines listed in the authors' profiles, the verification of the articles' content would be required. The analysis of bibliographic couplings shows that LIS and BMA are important to the publishing studies (Tab. 7).

Tab. 7 Core journals from C2 based on number of documents

with bibliographic coupling analysis (min. 10 documents, 100 citations, 100 TLS)

\begin{tabular}{|c|c|c|c|c|c|c|}
\hline No. & Title & $\begin{array}{c}\text { Documents } \\
2001-2018 / \\
\text { all }\end{array}$ & Category & ISSN & $\begin{array}{l}\text { TLS (bi- } \\
\text { bliographic } \\
\text { coupling) }\end{array}$ & $\begin{array}{l}\text { Cita- } \\
\text { tions }\end{array}$ \\
\hline 1 & $\begin{array}{l}\text { Publishing Research Qu- } \\
\text { arterly }\end{array}$ & $74 / 88$ & E: MT & $1053-8801$ & 279 & 270 \\
\hline 2 & Logos (The Netherlands) & $51 / 56$ & AH: LLT & $0957-9656$ & - & - \\
\hline 3 & $\begin{array}{l}\text { Journal of Scholarly Publi- } \\
\text { shing }\end{array}$ & $23 / 25$ & $\begin{array}{l}\text { E: MT / } \\
\text { SS: E }\end{array}$ & $1198-9742$ & 162 & 142 \\
\hline 4 & Learned Publishing & $19 / 22$ & SS: C & 0953-1513 & 153 & 261 \\
\hline 5 & Journal of Documentation & $15 / 18$ & SS: LIS/CS & $0022-0418$ & 326 & 382 \\
\hline 6 & $\begin{array}{l}\text { Journal of Librarianship } \\
\text { and Information Science }\end{array}$ & $15 / 24$ & SS: LIS & 0961-0006 & 185 & 206 \\
\hline 7 & Electronic Library & $14 / 18$ & SS: LIS/CS & 0264-0473 & 221 & 252 \\
\hline 8 & $\begin{array}{l}\text { Online Information } \\
\text { Review }\end{array}$ & $13 / 14$ & SS: LIS/CS & $1468-4527$ & 220 & 345 \\
\hline 9 & $\begin{array}{l}\text { Journal of Information } \\
\text { Science }\end{array}$ & $12 / 24$ & SS: LIS/CS & 0165-5515 & 218 & 914 \\
\hline 10 & $\begin{array}{l}\text { Journal of Media Econo- } \\
\text { mics }\end{array}$ & $12 / 13$ & $\begin{array}{l}\text { SS: C / } \\
\text { EEF }\end{array}$ & $0899-7764$ & 333 & 227 \\
\hline 11 & Information Research & 11 & SS: LIS & $1368-1613$ & 103 & 335 \\
\hline 12 & $\begin{array}{l}\text { Journal of Product and } \\
\text { Brand Management }\end{array}$ & $11 / 15$ & BMA & $1061-0421$ & - & - \\
\hline 13 & $\begin{array}{l}\text { Marketing Intelligence and } \\
\text { Planning }\end{array}$ & 11 & BMA & 0263-4503 & - & - \\
\hline 14 & $\begin{array}{l}\text { Journal of Marketing Ma- } \\
\text { nagement }\end{array}$ & $10 / 20$ & BMA & 0267-257X & 279 & 434 \\
\hline 15 & Library Management & $10 / 18$ & SS: LIS & $0143-5124$ & 60 & 391 \\
\hline 16 & Marketing Theory & $10 / 11$ & BMA & $1470-5931$ & 180 & 207 \\
\hline 17 & $\begin{array}{l}\text { International Journal of } \\
\text { Research in Marketing }\end{array}$ & $9 / 10$ & BMA & 0167-8116 & 245 & 184 \\
\hline 18 & $\begin{array}{l}\text { Journal of the American } \\
\text { Society for Information } \\
\text { Science and Technology }\end{array}$ & $9 / 11$ & $\begin{array}{l}\text { SS: LIS / } \\
\quad \text { CS }\end{array}$ & $1532-2882$ & 147 & 727 \\
\hline
\end{tabular}


The graph created with VOSviewer (Fig. 1) for the co-citation analysis of publication sources from C2 shows that the highest number of couplings (TLS) included Journal of Scholarly Publishing - JSP (the yellow cluster). There is a strong connection with PRQ (2737) and Harvard Business Review (1130). JSP was also related to journals concerned with marketing, management, economics and information science: Journal of Marketing (1693), Marketing Science (1483), Management Science (1478), Journal of The American Society for Information Science and Technology (1060). However, after the fractional counting method was applied, the importance of JSP and PRQ decreased (Fig. 2). The three clusters visible on the second graph encompass journals focused on marketing, management and economics (green and blue) and information science (red), connected to $P R Q^{15}$.

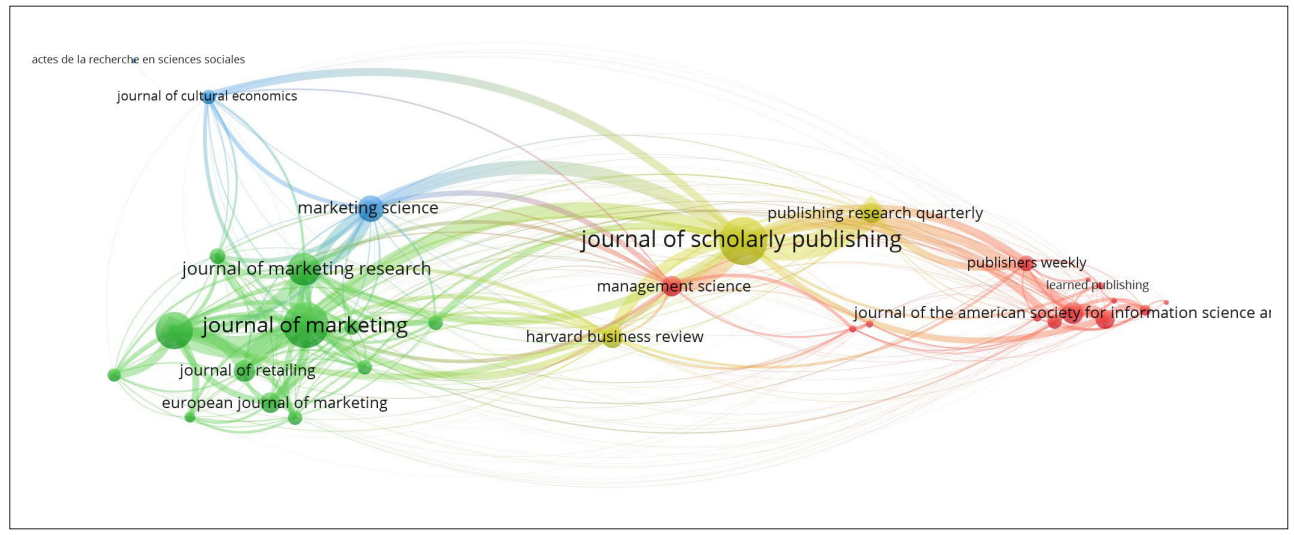

Fig. 1. Co-citation analysis of sources from $\mathrm{C} 2$

(min. 100 citations, weight TLS, full counting method)

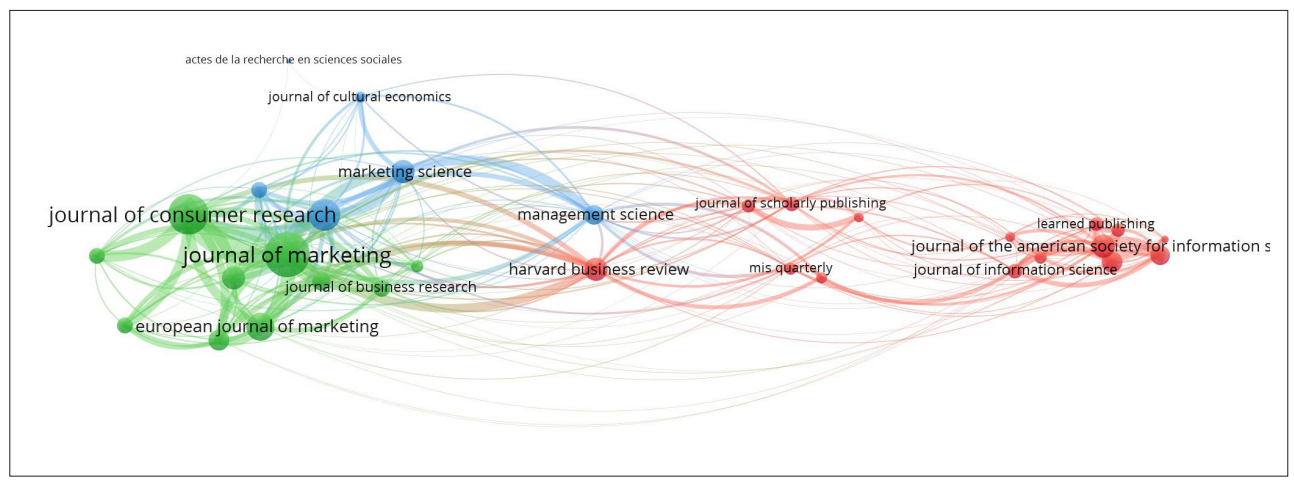

Fig. 2. Co-citation analysis of sources from $\mathrm{C} 2$

(min. 100 citations, weight TLS, fractional counting method)

15 This cluster encompasses journals such as Journal of Documentation, Electronic Library, and Scientometrics - concerned with Library and Information Studies - invisible on the graph. 


\section{Conclusion}

The field of book publishing studies is situated on the boundary of social sciences, humanities, and physical sciences. It is rooted in literary studies and book studies; it builds on the findings of information science and computer science; it borrows methods from sociology, culture studies and economics; as a result of the technological transformations, it studies new medias and technologies, which shape the product, the method of production, and the reception.

Between 2001 and 2018, research of the global book publishing market was dominated by the following issues:

- the research of the different types of books and literature in general, especially the need for bibliodiversity, diversify and democratize titles in response to globalization and the commercialization of culture;

- the effect of digitalization on various stakeholders: from authors small and independent publishers, which play important part in the innovation distribution chain, through the publishers of professional publications and university presses to the global commercial publishers of books and journals, the largest English-language trade and academic publishers and media-publishing syndicates;

- the transformation of business models, price strategies, and choices of distribution channels depending on the form of the book and the readers' preferences.

The book publishing market (global, or in the key markets) was a subject of research conducted by scholars with backgrounds in multiple disciplines. The initial study of their discipline profiles showed that approximately $70 \%$ (of 65) worked in at least five disciplines (usually SS, CS, BMA, E, and AH), and between 10 and 20\% were active in many research fields, publishing in a number of journals twice, or three times as high as the number of disciplines identified in their profiles (four and more). Qualitative analysis of the publications comprising $\mathrm{C} 1$ showed that the authors whose profiles featured between four and six disciplines, publishing in a similar number of journals, made a larger impact. Combining perspectives particular to specific disciplines, they sought to integrate the knowledge of the book publishing market as a material, multi-dimensional object of study (Walczak, 2016, 122). Despite the interdisciplinarity of the researchers, there was little international collaboration.

The major journals in the field of publishing studies include Publishing Research Quarterly (E: MT, SS: C), Logos (AH: LLT, E: MT), Journal of Scholarly Publishing (E: MT, SS: E) and Learned Publishing (SS: C). Articles published in the journals associated with information studies, Electronic Library, Journal of Documentation, and Journal of Librarianship and Information Sciences constituted a large part of both corpuses. Co-citation analysis showed that trade journals $(\mathrm{C} 1)$ and journals focusing on marketing, management, and information science $(\mathrm{C} 2)$ play an important role in the book publishing market studies.

A more detailed analysis of the research areas of publishing studies and the key authors, combined with an analysis of institutions with which they are associated, accounting for the previously omitted types of publications and articles from the indicated journals, should fill out, or correct, the results of the present study. In the further research on global publishing it will be necessary to take into account emerging markets and developing countries such as India, Brazil or Mexico, where demographic conditions generate a potential for more rapid educational and economic growth. 


\section{Data Availability}

\section{Special bibliography:}

Augustyn, K. (2018). Źródta informacji o globalnym rynku ksiażki w latach 2001-2017. Wersja 1. Pracownia Humanistyki Cyfrowej, http://phc.uni.wroc.pl/bibliografie/rynek_show.php

Augustyn, K. (2020). Źródła informacji o globalnym rynku książi po 2001 roku / Sources of information regarding the global book publishing market after 2001. Wersja 2. Pracownia Humanistyki Cyfrowej, http://phc.uni.wroc.pl/pl/Bibliografie_spec.html (2020-08-01). Plik XLS: http://phc.uni. wroc.pl/pl/assets/files/Global_book_publishing_2001_2018_Augustyn.xls

\section{Bibliography for this study from Corpus 1 (C1):}

Augustyn, K. (2020). Corpus 1 (C1): The Global Book Publishing Market as an Interdisciplinary Research Field, Pracownia Humanistyki Cyfrowej, http://phc.uni.wroc.pl/pl/Bibliografie_spec. html. Plik XLS: http://phc.uni.wroc.pl/pl/assets/files/Augustyn_Corpus1_The_Global_Book_Publishing_Market.xls

\section{References}

Alptekin, G. I. (2015). Strategic Pricing Model Based on Genetic Algorithm: The Case of Electronic Publishing Market. Journal of Intelligent \& Fuzzy Systems, 29(4), 1551-1564, https://doi.org/10.3233/IFS-151634

Andrews, K., Napoli, P. M. (2006). Changing Market Information Regimes: A Case Study of the Transition to the Bookscan Audience Measurement System in the Us Book Publishing Industry. Journal of Media Economics, 19(1), 33-54, https://doi.org/10.1207/s15327736me1901_3

Artiles, M., Beaulieu, C., Carey, S., Danza, M., Gatian, A., Gavin, A., ... Wharton, R. M. (2013). The Impact of E-Readers and E-Books on the Library of Congress and the Us Copyright Office. Journal of Scholarly Publishing, 45(1), 1-34, https://doi.org/10.3138/jsp.45-1-001

Asai, S. (2015). Purchase Patterns of Popular Japanese Novels in Hardcover and Paperback. Publishing Research Quarterly, 31(3), 149-159, https://doi.org/10.1007/s12109-015-9409-4

Asai, S. (2016). Determinants of Demand and Price for Best-Selling Novels in Paperback in Japan. Journal of Cultural Economics, 40(4), 375-392, https://doi.org/10.1007/s10824-015-9256-3

Bailey, C. W. (2001). Evolution of an Electronic Book: The Scholarly Electronic Publishing Bibliography. The Journal of Electronic Publishing, 7(2), http://hdl.handle.net/10150/105451

Ban, A. (2015). Books in Translation in the United States. Publishing Research Quarterly, 31(3), 160-174, https://doi.org/10.1007/s12109-015-9406-7

Baverstock, A., Steinitz, J. (2014). How Is the Discipline of Publishing Studies Accommodated Within Universities?. Learned Publishing, 27(4), 291-300, https://doi.org/10.1087/20140409

Beetz, A. (2008). Selling Digital Rights as a General Publisher: Text and Images. Publishing Research Quarterly, 24(2), 129-132, https://doi.org/10.1007/s12109-008-9071-1

Benhamou, F., Peltier, S. (2007). How Should Cultural Diversity Be Measured? An Application Using the French Publishing Industry. Journal of Cultural Economics, 31(2), 85-107, https://doi. org/10.1007/s10824-007-9037-8

Birtle, R. (2011). The Development and Future of the Japanese Ebook Market. Publishing Research Quarterly, 27(4), 345-353, https://doi.org/10.1007/s12109-011-9247-y

Bold, M. R. (2015). Standing in the Shadow of Giants: Publishing in the Midlands and North of England. Logos, 26(4), 37-50, https://doi.org/10.1163/1878-4712-11112089

Bold, M. R. (2016). An "Accidental Profession": Small Press Publishing in the Pacific Northwest. Publishing Research Quarterly, 32(2), 84-102, https://doi.org/10.1007/s12109-016-9452-9

Bold, M. R. (2018). The Eight Percent Problem: Authors of Colour in the British Young Adult Market (2006-2016). Publishing Research Quarterly, 34(3), 385-406, https://doi.org/10.1007/s12109-018-9600-5 
Bold, M. R., Norrick-Rühl, C. (2017). The Independent Foreign Fiction Prize and Man Booker International Prize Merger: Can the Man Booker Association Help With the Three per Cent Problem? Logos, 28(3), 7-24, https://doi.org/ 10.1163/1878-4712-11112131

Brienza, C. E. (2009). Books, Not Comics: Publishing Fields, Globalization, and Japanese Manga in the United States. Publishing Research Quarterly, 25(2), 101-117, https://doi.org/10.1007/s12109-009-9114-2

Brienza, C. (2010). Producing Comics Culture: A Sociological Approach to the Study of Comics. Journal of Graphic Novels and Comics, 1(2), 105-119, https://doi.org/10.1080/21504857.2010.528638

Brown, S., Patterson, A. (2010). Selling Stories: Harry Potter and the Marketing Plot. Psychology E Marketing, 27(6), 541-556, https://doi.org/10.1002/mar.20343

Burleigh, D. (2017). Using Consumer Data to Illustrate How the Library Channel Drives Digital Sales. Publishing Research Quarterly, 33(4), 380-391. DOI: 10.1007/s12109-017-9555-y

Buschow, C., Nölle, I., \& Schneider, B. (2014). German Book Publishers' Barriers to Disruptive Innovations: The Case of E-Book Adoption. Publishing Research Quarterly, 30(1), 63-76, https:// doi.org/10.1007/s12109-014-9342-y

Carolan, S., Evain, C. (2013). Self-publishing: Opportunities and Threats in a New Age of Mass Culture. Publishing Research Quarterly, 29(4), 285-300, https://doi.org/10.1007/s12109-013-9326-3

Clare, J. (2014). University Presses in the Digital Age: How Pace University Press and Other University Presses Can Survive and Thrive. Publishing Research Quarterly, 30(2), 195-211, https://doi. org/10.1007/s12109-014-9362-7

Costa-Knufinke, J. (2012). Overview of the Spanish Ebook Market. Publishing Research Quarterly, 28(2), 135-142, https://doi.org/10.1007/s12109-012-9260-9

Emblidge, D. (2012). The Gotham Bookmart: Location, Location, Location. International Journal of the Book, 9(4), 147-160, https://doi.org/10.18848/1447-9516/CGP/v09i04/36917

Emblidge, D. (2013). Borders"Concept Store.'Logos, 24(3), 7-19, https://doi.org/10.1163/1878-471211112021

Emblidge, D. (2015). A Publishing Studies Online Academic Database: In-Progress Research Project. Publishing Research Quarterly, 31(3), 178-182, https://doi.org/10.1007/s12109-015-9410-y

Emblidge, D. (2016). Kepler's Angels, Big and Small. Logos, 27(4), 7-17, https://doi.org/10.1163/18784712-11112113

Esposito, J. J. (2010). Creating a Consolidated Online Catalogue for the University Press Community. Journal of Scholarly Publishing, 41(4), 385-427, https://doi.org/10.3138/jsp.41.4.385

Faherty, A. (2013). Curiouser and Curiouser: Novelty-Centred Business Models and Value Creation in Established Publishing Firms. International Journal of the Book, 11(1), 39-57, https://doi. org/10.18848/1447-9516/CGP/v11i01/37006

Feather, J., Woodbridge, H. (2007). Bestsellers in the British Book Industry 1998-2005. Publishing Research Quarterly, 23(3), 210-223, https://doi.org/10.1007/s12109-007-9013-3

Forzetting, S., Wiersma, G., Eager, L. (2012). Managing E-Book Acquisition: The Coordination of "P" and "E" Publication Dates. The Serials Librarian, 62(1-4), 200-205, https://doi.org/10.1080/0361526X.2012.652921

Friesen, N. (2013). The Past and Likely Future of an Educational Form: A Textbook Case. Educational Researcher, 42(9), 498-508, https://doi.org/10.3102/0013189X13513535

Fröhlich, R. (2014). Book People in Germany: A Study on the Professional Situation and Career Conditions of Men and Women in the German Book Publishing Industry and the Book Trade. Publishing Research Quarterly, 30(2), 223-243, https://doi.org/10.1007/s12109-014-9361-8

Gallagher, K., Bohme, S. (2009). A Special Relationship? A Comparison of Consumer Book Buying Habits and Trends in the United States and Great Britain. Publishing Research Quarterly, 25(4), 246-253, https://doi.org/10.1007/s12109-009-9139-6

Greco, A. (2005). A Bibliography of Books and Journal Articles on Scholarly Publishing. Journal of Scholarly Publishing, 37(1), 48-54, https://doi.org/: 10.3138/jsp.37.1.48 
Greco, A. N. (2001). The Market for University Press Books in the United States: 1985-1999. Learned Publishing, 14(2), 97-105, https://doi.org/10.1087/095315101300059459

Greco, A. N., Wharton, R. M., Sen, F. (2012). The Price of University Press Books: 2009-2011. Journal of Scholarly Publishing, 43(4), 363-380, https://doi.org/10.3138/jsp.43.4.363

Greco, A. N., Aiss, C. G. (2015). University Presses in the Twenty-First Century: The Potential Impact of Big Data and Predictive Analytics on Scholarly Book Marketing. Journal of Scholarly Publishing, 46(2), 105-140, https://doi.org/10.3138/jsp.46.2.01

Greco, A. N., Spendley, A. M. (2016). The Price of University Press Books, 2012-14. Journal of Scholarly Publishing, 47(2), 106-120, https://doi.org/10.3138/jsp.47.2.106

Haeusermann, T. (2013). Custom Publishing in the UK: Rise of a Silent Giant. Publishing Research Quarterly, 29(2), 99-109, https://doi.org/10.1007/s12109-013-9310-y

Hao, L., Fan, M. (2014). An Analysis of Pricing Models in the Electronic Book Market. MIS Quarterly, 38(4), 1017-1032, https://doi.org/10.2307/26627960

Hawthorne, S. (2016). Bibliodiversity: Creating Content or Invigorating Culture? Logos, 27(1), 63-71, https://doi.org/10.1163/1878-4712-11112099

Herther, N. K. (2005). The E-Book Industry Today: A Bumpy Road Becomes an Evolutionary Path to Market Maturity. The Electronic Library, 23(1), 45-53, https://doi.org/10.1108/02640470510582727

Himma, K. E., Just, P. (2007). Electronic Books in the USA-Their Numbers and Development and a Comparison to Germany. Library Hi Tech, 25(1), 157-164. DOI: 10.1108/07378830710735939

House, E. (2013). Challenges Facing the UK Book Industry. Publishing Research Quarterly, 29(3), 211-219, https://doi.org/: 10.1007/s12109-013-9320-9

$\mathrm{Hu}$, J., Zhang, Y. (2016). Understanding Chinese Undergraduates' Continuance Intention to Use Mobile Book-Reading Apps: An Integrated Model and Empirical Study. Libri, 66(2), 85-99, https:// doi.org/10.1515/libri-2015-0090

Jin, B. H., Li, Y. M. (2012). Analysis of Emerging Technology Adoption for the Digital Content Market. Information Technology and Management, 13(3), 149-165, https://doi.org/10.1007/s10799-011-0113-6

Joseph, R.P. (2015). Higher Education Book Publishing_From Print to Digital: A Review of the Literature. Publishing Research Quarterly, 31(4), 264-274, https://doi.org/10.1007/s12109-015-9429-0

Kernan, M. A. (2013). When Is a Publishing Business Truly 'Global'? An Analysis of a Routledge Case Study With Reference to Ohmae's Theory of Globalization. Publishing Research Quarterly, 29(4), 344-364, https://doi.org/10.1007/s12109-013-9329-0

Kovač, M. (2007). Reading the Texts on Book Publishing: A New Body of Knowledge About an Old Body of Knowledge. Publishing Research Quarterly, 23(4), 241-253, https://doi.org/10.1007/s12109-007-9030-2

Kovač, M., Wischenbart, R. (2010). A Myth Busted: Bestselling Fiction in Europe and Slovenia. Primerjalna Književnost, 33(2), 117-135+287-305.

Kovač, M., Phillips, A., van der Weel, A., Wischenbart, R. (2017). Book Statistics: What Are They Good For? Logos, 28(4), 7-17, https://doi.org/10.1163/1878-4712-11112137

Kovač, M., van der Weel, A. (2018). Reading in a Post-Textual Era [online]. First Monday, 23(10) [09.09.2020], https://doi.org/: 10.5210/fm.v23i10.9416

Kovač, M., Wischenbart R. (2018). Bestsellers 2008 to 2014: The Last King of Analogue and the First Dame of the Digital Pleasure House. Logos 29(1), 18-27, https://doi.org/10.1163/18784712-02901003

Laakso, M., Welling, P., Bukvova, H., Nyman, L., Björk, B. C., Hedlund, T. (2011). The Development of Open Access Journal Publishing from 1993 to 2009. PloS One, 6(6), e20961, 1-10, https://doi. org/10.1371/journal.pone.0020961

Li, Y., Lin, Z., Xu, L., Swain, A. (2015). "Do the Electronic Books Reinforce the Dynamics of Book Supply Chain Market?"- a Theoretical Analysis. European Journal of Operational Research, 245(2), 591-601, https://doi.org/:10.1016/j.ejor.2015.01.048

Lian, X. C. (2010). Publisher's Dilemma From Penguin Books to E-Books. Logos, 21(3-4), 37-46, https://doi.org/:10.1163/095796511X559936 
Lichtenberg, J. (2011). In From the Edge: The Progressive Evolution of Publishing in the Age of Digital Abundance. Publishing Research Quarterly, 27(2), 101-112, https://doi.org/10.1007/s12109-011-9212-9 Liu, B. (2008). Use of Digitization to Modernize China's Publishing Industry. Publishing Research Quarterly, 24(1), 40-47, https://doi.org/10.1007/s12109-008-9064-0

Machovec, G. (2018). Consortial Ebook Archiving Environmental Scan. Journal of Library Administration, 58(1), 81-90, https://doi.org/: 10.1080/01930826.2017.1399706

Magadán, M., Rivas, J. (2018). The Impact of Digitization on the Spanish Publishing Industry. The International Journal of the Book, 16(2), 1-18, https://doi.org/10.18848/1447-9516/CGP/v16i02/1-18

Mangen, A., Van der Weel, A. (2016). The Evolution of Reading in the Age of Digitisation: An Integrative Framework for Reading Research. Literacy, 50(3), 116-124, https://doi.org/10.1111/lit.12086

Mannana-Rodriguez, J., Giménez-Toledo, E. (2018). Specialization and Multidisciplinarity of Scholarly Book Publishers: Differences Between Spanish University Presses and Other Scholarly Publishers. Scientometrics, 114(1), 19-30, https://doi.org/10.1007/s11192-017-2563-z

Marcus, L.S. (2016). The Global/Local Book Publishing (R)evolution. Publishing Research Quarterly, 32(1), 64-69, https://doi.org/: 10.1007/s12109-015-9441-4

Martin, A., Bartscher-Finzer, S., Richards, A. (2018). The Motivations of Book Publishers in Germany and Australia: An Empirical Comparison. Publishing Research Quarterly, 34(1), 69-88, https:// doi.org/: 10.1007/s12109-018-9570-7

Mcllroy, T. (2017). Startups Within the US Book Publishing Industry. Publishing Research Quarterly, 33(1), 1-9, https://doi.org/10.1007/s12109-017-9500-0

Milliot, J. (2018). The World's 54 Largest Publishers, 2018. The U.K. Educational Publishers Remained the World's Largest Publisher in 2017 [online]. Publishers Weekly [09.09.2020], https://www. publishersweekly.com/pw/by-topic/industry-news/publisher-news/article/78036-pearson-is-stillthe-world-s-largest-publisher.html

Mizrachi, D., Salaz, A. M., Kurbanoglu, S., Boustany, J., ARFIS Research Group. (2018). Academic Reading Format Preferences and Behaviors Among University Students Worldwide: A Comparative Survey Analysis. PloS One, 13(5), https://doi.org/10.1371/journal.pone.0197444

Moeller, R. A., Becnel, K. (2018). Drawing Diversity: Representations of Race in Graphic Novels for Young Adults [online]. School Library Research, 21 [09.09.2020], https://files.eric.ed.gov/fulltext/ EJ1182162.pdf

Murray, S. (2006). Publishing Studies: Critically Mapping Research in Search of a Discipline. Publishing Research Quarterly, 22(4), 3-25, https://doi.org/10.1007/s12109-007-0001-4

Murray, S. (2016). 'Selling'Literature: The Cultivation of Book Buzz in the Digital Literary Sphere. Logos, 27(1), 11-21, https://doi.org/10.1163/1878-4712-11112094

Ohlsson, A., Forslid, T., Steiner, A. (2014). Literary Celebrity Reconsidered. Celebrity Studies, 5(1-2), 32-44, https://doi.org/: 10.1080/19392397.2014.887533

Osiński, Z. (2019). The Usefulness of Data From Web of Science and Scopus Databases for Analyzing the State of a Scientific Discipline. the Case of Library and Information Science. Zagadnienia Informacji Naukowej - Studia Informacyjne, 57(2A), 94-106, https://doi.org/:10.36702/zin.469

Overdorf, M., Barragree, A. (2001). The Impending Disruption of the Publishing Industry. Publishing Research Quarterly, 17(3), 3-18, https://doi.org/:10.1007/s12109-001-0027-y

Patterson, T., Brown, S. (2009). Never Tickle a Sleeping Bookworm: How Readers Devour Harry Potter. Marketing Intelligence \& Planning, 27(6), 818-832, https://doi.org/: 10.1108/02634500910988708

Pehar, F., Selthofer, J. (2015). Towards a Better Understanding of Publishing Studies Based on Course Syllabi Reading Lists [online]. Books and reading in an age of media overload. By the Book. International Symposium, Florence, Italy, 18-19 June 2015 [09.09.2020], https://bib.irb.hr/datoteka/766556.ByTheBook2_FP_JS_2015.pdf

Peltier, S. (2004). Mergers and Acquisitions in the Media Industries: Were Failures Really Unforeseeable? Journal of Media Economics, 17(4), 261-278, https://doi.org/10.1207/s15327736me1704_2 
Peltier, S., Benhamou, F., Touré, M. (2016). Does the Long Tail Really Favor Small Publishers? Journal of Cultural Economics, 40(4), 393-412, https://doi.org/10.1007/s10824-015-9257-2

Rimm, A. M. (2014). Conditions and Survival: Views on the Concentration of Ownership and Vertical Integration in German and Swedish Publishing. Publishing Research Quarterly, 30(1), 77-92, https://doi.org/10.1007/s12109-014-9353-8

Roosendaal, H. E., Huibers, T. W., Peter, A. T. M., van der Vet, P. E. (2003). Changes in the Value Chain of Scientific Information: Economic Consequences for Academic Institutions. Online Information Review, 27(2), 120-128, https://doi.org/10.1108/14684520310471734

Rose, J. (2003). The Horizon of a New Discipline: Inventing Book Studies. Publishing Research Quarterly, 19(1), 11-19, https://doi.org/10.1007/s12109-003-0019-1

Sapiro, G. (2008). Translation and the Field of Publishing: A Commentary on Pierre Bourdieu's “A Conservative Revolution in Publishing". Translation Studies, 1(2), 154-166, https://doi. org/10.1080/14781700802113473

Sapiro, G. (2010). Globalization and Cultural Diversity in the Book Market: The Case of Literary Translations in the US and in France. Poetics, 38(4), 419-439, https://doi.org/10.1016/j.poetic.2010.05.001

Sapiro, G. (2015). Translation and Symbolic Capital in the Era of Globalization: French Literature in the United States. Cultural Sociology, 9(3), 320-346, https://doi.org/10.1177/1749975515584080

Sapiro, G. (2016). The Metamorphosis of Modes of Consecration in the Literary Field: Academies, Literary Prizes, Festivals. Poetics, 59, 5-19, https://doi.org/10.1016/j.poetic.2016.01.003

Sapiro, G. (2017). The Role of Publishers in the Making of World Literature: The Case of Gallimard. Letteratura e letterature, 11, 81-93, https://doi.org/: 10.19272/201709801008

Schmidt-Stölting, C., Blömeke, E., Clement, M. (2011). Success Drivers of Fiction Books: An Empirical Analysis of Hardcover and Paperback Editions in Germany. Journal of Media Economics, 24(1), 24-47, https://doi.org/: 10.1080/08997764.2011.549428

Shea, N., Mulvihill, G., La Bianca, V., Hanchar, A. (2018). Who Is Publishing Diverse Books Best?. Publishing Research Quarterly, 34(2), 207-217, https://doi.org/10.1007/s12109-018-9573-4

Shehu, E., Prostka, T., Schmidt-Stölting, C., Clement, M., Blömeke, E. (2014). The Influence of Book Advertising on Sales in the German Fiction Book Market. Journal of Cultural Economics, 38(2), 109-130, https://doi.org/10.1007/s10824-013-9203-0

Shimray, S. R., Keerti, C., Ramaiah, C. K. (2015). An Overview of Mobile Reading Habits. DESIDOC Journal of Library \& Information Technology, 35(5), 343-354, https://doi.org/10.14429/djlit.35.5.8901

Sorensen, A. T. (2007). Bestseller Lists and Product Variety. The Journal of Industrial Economics, 55(4), 715-738, https://doi.org/10.1111/j.1467-6451.2007.00327.x

Squires, C. (2004). A Common Ground? Book Prize Culture in Europe. Javnost-The Public, 11(4), 37-47, https://doi.org/: 10.1080/13183222.2004.11008866

Steiner, A. (2017). Select, Display, and Sell: Curation Practices in the Bookshop. Logos, 28(4), 18-31, https://doi.org/10.1163/1878-4712-11112138

Steiner, A. (2018). The Global Book: Micropublishing, Conglomerate Production, and Digital Market Structures. Publishing Research Quarterly, 34(1), 118-132, https://doi.org/10.1007/s12109-017-9558-8

Stepanova, M. (2007). Disciplinary Duality: The Contested Terrain of Book Studies. Publishing Research Quarterly, 23(2), 105-115, https://doi.org/10.1007/s12109-007-9018-y

Stevenson, I. (2008). Harry Potter, Riding the Bullet and the Future of Books: Key Issues in the Anglophone Book Business. Publishing Research Quarterly, 24(4), 277-284, https://doi.org/10.1007/ s12109-008-9086-7

Striphas, T. (2002). Banality, Book Publishing and the Everyday Life of Cultural Studies. International Journal of Cultural Studies, 5(4), 438-460.

Striphas, T. (2006). Disowning Commodities: Ebooks, Capitalism, and Intellectual Property Law. Television \& New Media, 7(3), 231-260, https://doi.org/10.1177/1527476404270551 
Striphas, T. (2009). Harry Potter and the Simulacrum: Contested Copies in an Age of Intellectual Property. Critical Studies in Media Communication, 26(4), 295-311, https://doi.org/10.1080/ 15295030903177516

Thomlison, A., Bélanger, P. C. (2015). Authors' Views of E-Book Self-Publishing: The Role of Symbolic Capital Risk. Publishing Research Quarterly, 31(4), 306-316, https://doi.org/10.1007/s12109-015-9422-7

Tian, X., Martin, B. (2013). Value Chain Adjustments in Educational Publishing. Publishing Research Quarterly, 29(1), 12-25, https://doi.org/10.1007/s12109-012-9303-2

Tovstiadi, E., Wiersma, G. (2016). Comparing Digital Apples and Oranges: A Comparative Analysis of E-Books Across Multiple Platforms. The Serials Librarian, 70(1-4), 175-183, https://doi.org/10.1080/0361526X.2016.1148979

Van Eck, N.J., Waltman, L. (2010). Software Survey: Vosviewer, a Computer Program for Bibliometric Mapping. Scientometrics, 84(2), 523-538, https://doi.org/10.1007/s11192-009-0146-3

Vasileiou, M., Hartley, R., Rowley, J. (2009). An Overview of the E-Book Marketplace. Online Information Review, 33(1), 173-192, https://doi.org/10.1108/14684520910944454

Vasileiou, M., Rowley, J., Hartley, R. (2012). Perspectives on the Future of E-Books in Libraries in Universities. Journal of Librarianship and Information Science, 44(4), 217-226, https://doi. org/10.1177/0961000611434759

Von Rimscha, M. B., Putzig, S. (2013). From Book Culture to Amazon Consumerism: Does the Digitization of the Book Industry Lead to Commercialization?. Publishing Research Quarterly, 29(4), 318-335, https://doi.org/10.1007/s12109-013-9327-2

Walczak, M. (2016). Czy możliwa jest wiedza interdyscyplinarna? [online]. Zagadnienia Naukoznawstwa, 1(207), 113-126 [09.09.2020], https://journals.pan.pl/Content/94261/mainfile.pdf

Weinstein, A. (2010). A Look at Global Expansion for E-Books. Publishing Research Quarterly, 26(1), 11-15, https://doi.org/10.1007/s12109-010-9148-5

Williams, E. (2011). Copyright, E-Books and the Unpredictable Future. Publishing Research Quarterly, 27(1), 19-25, https://doi.org/10.1007/s12109-010-9196-x

Williams, P., Stevenson, I., Nicholas, D., Watkinson, A., Rowlands, I. (2009). The Role and Future of the Monograph in Arts and Humanities Research. Aslib Proceedings, 61(1), 67-82, https://doi. org/10.1108/00012530910932294

Wischenbart, R. (2016). The Business of Books 2016: Between the First and the Second Phase of Transformation. An overview of market trends in North America, Europe, Asia and Latin America, and a look beyond books. Frankfurt: Frankfurter Buchmesse.

Wischenbart, R. (2018). Business of Books 2018. New Tuned for an Old Trade [online]. Frankfurt: Frankfurter Buchmesse [09.09.2020], https://www.buchmesse.de/files/media/pdf/FBM_WhitePaper_The_Business_of_Books_2018.pdf

Wischenbart R., Fleischhacker M.A. (2019). Global 50. the World Ranking of the Publishing Industry 2019 [online]. Paris: Livres Hebdo [09.09.2020], https://www.publishersweekly.com/binary-data/ Global502019.pdf

Xiaomei, C. (2011). 2010: The Turning Point for Chinese Book Publishing Industry. Publishing Research Quarterly, 27(1), 76-82, https://doi.org/10.1007/s12109-011-9203-x

Xu, L., Fang, Q. (2008). Chinese Publishing Industry Going Global: Background and Performance. Publishing Research Quarterly, 24(1), 64-72, https://doi.org/10.1007/s12109-008-9045-3

Zhang, W. (2008). Effects of Promotion in the Three Media on Book Sales. Publishing Research Quarterly, 24(1), 27-31, https://doi.org/10.1007/s12109-008-9061-3

Zins, C. (2007). Classification Schemes of Information Science: Twenty Eight Scholars Map the Field. Journal of the American Society for Information Science and Technology, 58(5), 645-672, https:// doi.org/10.1002/asi.20506 


\title{
Globalny rynek książki jako interdyscyplinarny obszar badań
}

\begin{abstract}
Abstrakt
Cel/Teza: Celem artykułu jest charakterystyka badań globalnego rynku książki, zmierzająca do wykazania stopnia ich interdyscyplinarności.

Koncepcja/Metody badań: Analizy jakościowa i ilościowa wybranych artykułów naukowych, profili dyscyplinarnych ich autorów i czasopism oraz struktury piśmiennictwa przy użyciu bibliometrycznych metod (analiza współcytowań i powiązań bibliograficznych) oraz technologii wizualizacji wiedzy posłużyła do ustalenia, w pola badawcze jakich dyscyplin wpisuje się problematyka podejmowana przez badaczy.

Wyniki i wnioski: Wybrane publikacje dotyczyły: book history \& book culture, economics \& technological elements of book publishing, user attitudes \& preferences. Autorzy publikowali głównie w czasopismach z: media \& communication studies, education (Publishing Research Quarterly, Journal of Scholarly Publishing, Learned Publishing), book studies (Logos) i information studies (Electronic Library, Journal of Documentation). Współcytowane były czasopisma branżowe (C1) oraz naukowe, głównie z marketingu i ekonomii (C2). Publikacje współautorskie stanowiły: 42\% (C1) i 63\% (C2). Badania nad globalnym rynkiem książki są prowadzone przez multidyscyplinarnych badaczy, ale rzadko jeszcze przez międzynarodowe zespoły.

Ograniczenia badań: Wstępny korpus publikacji zawężono do 230 artykułów w języku angielskim, opublikowanych między 2001 a 2018 r. Nie zostały w nim uwzględnione artykuły na temat rynków książki krajów, których udział w globalnej produkcji wydawniczej jest niewielki. Kategoryzacje dyscyplinarne pochodzą z bazy Scopus.

Oryginalność/Wartość poznawcza: Artykuł oferuje wgląd w specyfikę badań nad globalnym rynkiem książki i dowodzi, że jest to obszar będący wspólnym punktem odniesienia dla badaczy reprezentujących wiele dyscyplin.
\end{abstract}

\section{Słowa kluczowe}

Bibliometria. Czasopisma naukowe. Globalny rynek książki. Interdyscyplinarność. Przemysł wydawniczy. Publikowanie książek. Rynek książki. Studia wydawnicze. Źródła informacji.

KAMILA AUGUSTYN, PhD, is Assistant Professor in the Department of Book Theory and History at the Institute of Library and Information Science at the University of Wroctaw. Her main interests are: theory and history of literature, book publishing market, the art of editing, science and higher education research. Her major publications include: Wroctaw. Literacka geografia miasta (2017); Rola i znaczenie Uniwersytetu w obliczu przemian dokonywanych na rzecz utowarowienia wiedzy (Nauka, 2019); Analiza sposobów zaangażowania we współtworzenie Wikipedii w świetle koncepcji ekonomii współpracy (Zagadnienia Informacji Naukowej, 2019); Kulturotwórczy potencjał nowych mediów (Zagadnienia Rodzajów Literackich, 2019).

Contact to the Author:

kamila.augustyn@uwr.edu.pl

Institute of Library and Information Science

University of Wroctaw

pl. Uniwersytecki 9/13

50-137 Wroctaw, Poland 